\title{
EDUCATING FOR SOCIAL JUSTICE IN A POST-DIGITAL ERA
}

\author{
EDUCANDO PARA A JUSTIÇA SOCIAL NA ERA PÓS-DIGITAL
}

EDUCANDO PARA LA JUSTICIA SOCIAL EN LA ERA POST-DIGITAL

\author{
Paulo Boa Sorte \\ Universidade Federal de Sergipe - Brasil \\ Cristiane Vicentini \\ University of Miami - Estados Unidos da América
}

\begin{abstract}
This article focuses on education for social justice in a post-digital area. Nowadays, common sentiments of disenchantment and skepticism with technology are expressed by teachers' choices of using or foregoing advanced technologies in their classrooms, either because they do not have access to them or because they are not properly taught (nor even trained) to use them. On the side of the students, post-truth, misinformation and disinformation have been blurring the way that contents and their relationship with the world should be considered. We define education for social justice, given the significant and substantial studies in the field (FREIRE, 1974/2010; MCDONALD, 2005, 2007, MCDONALD \& ZEICHNER, 2009; LEONARD ET AL, 2010; AGARVAL ET AL, 2010; DE OLIVEIRA, 2013). We also deepen conceptions that we consider to be essential for confronting problems of the post-digital era: (i) attention to neoliberalism and its impacts on education for social justice (HURSH, 2005; COCHRAN-SMITH ET AL, 2009; SLEETER, 2009; MILNER, 2010); (ii) attention to race, racism, and a claim for anti-oppressive education (LADSON-BILLINGS \& TATE, 1995; KUMASHIRO, 2000, 2001; BANKS, 2001; RICHERT ET AL, 2009; YOUNG, 2010; SLEETER, 2017). Our conclusions are geared towards the post-digital era, when access to data and the latest technology remains limited to those in positions of power. Teacher and teacher educators should strive to create environments which encourage exposure to perspectives that are inclusive of marginalized groups and allow for further understanding of a variety of ethnicities, cultures, socioeconomical backgrounds, and sexual orientations.
\end{abstract}

Keywords: Education; Social Justice; Post-digital era.

Resumen: Este artículo se centra en la educación para la justicia social en el área post-digital. Hoy, los sentimientos comunes de desencanto y escepticismo sobre la tecnología se expresan en las elecciones de los maestros para usar o prescindir del uso de tecnologías avanzadas en sus aulas, ya sea porque no tienen acceso a ellas o porque no se les ha enseñado (ni siquiera capacitado) ) para usarlos. Del lado de los estudiantes, la post-verdad y la desinformación han oscurecido la forma en que se debe considerar el contenido y sus relaciones con el mundo. Definimos la educación para la justicia social, dados los estudios significativos y sustanciales en el campo (FREIRE, 1974/2010; MCDONALD, 2005, 2007, MCDONALD \& ZEICHNER, 2009; LEONARD ET AL, 2010; AGARVAL ET AL, 2010; DE OLIVEIRA, 2013 ) También profundizamos conceptos que consideramos esenciales para enfrentar los problemas de la era post-digital: (i) atención al neoliberalismo y sus impactos en la educación para la justicia social (HURSH, 2005; COCHRAN-SMITH ET AL, 2009; SLEETER, 2009; MILNER, 2010); 
(ii) atención a la raza, el racismo y la demanda de educación contra la opresión (LADSON-BILLINGS AND TATE, 1995; KUMASHIRO, 2000, 2001; BANKS, 2001; RICHERT ET AL, 2009; YOUNG, 2010 ; SLEETER, 2017). Nuestras conclusiones se centran en la era post-digital, cuando el acceso a los datos y la última tecnología sigue siendo limitado para aquellos en posiciones de poder. Los maestros y educadores deben esforzarse por crear entornos que fomenten la exposición a perspectivas que incluyan grupos marginados y permitan una mayor comprensión de una variedad de etnias, culturas, antecedentes socioeconómicos y orientaciones sexuales.

Palabras llave: Educación; Justicia social; Era post-digital.

Resumo: Este artigo discute a educação para a justiça social na era pós-digital. Hoje em dia, sentimentos comuns de desencanto e ceticismo com a tecnologia são expressos pelas escolhas dos professores em usar ou dispensar tecnologias avançadas em suas salas de aula, seja porque não têm acesso a elas ou porque não foram ensinados (nem mesmo treinados) para fazê-lo. Do lado dos alunos, pós-verdade e desinformação têm obscurecido a maneira como os conteúdos e suas relações com o mundo precisam ser considerados. Definimos educação para a justiça social, a partir dos estudos significativos e substanciais da área (FREIRE, 1974/2010; MCDONALD, 2005, 2007, MCDONALD E ZEICHNER, 2009; LEONARD ET AL, 2010; AGARVAL ET AL, 2010; DE OLIVEIRA, 2013). Também aprofundamos concepções que consideramos essenciais para enfrentar os problemas da era pós-digital: (i) atenção ao neoliberalismo e seus impactos na educação para a justiça social (HURSH, 2005; COCHRAN-SMITH ET AL, 2009; SLEETER, 2009 ; MILNER, 2010); (ii) atenção à raça, racismo e uma reivindicação por educação anti-opressora (LADSON-BILLINGS E TATE, 1995; KUMASHIRO, 2000, 2001; BANKS, 2001; RICHERT ET AL, 2009; YOUNG, 2010; SLEETER, 2017). Nossas conclusões são direcionadas à era pós-digital, quando o acesso a dados e às mais recentes tecnologias permanecem limitados àqueles em posições de poder. O professor e os educadores podem se envolver na criação de ambientes que incentivem a exposição a perspectivas que incluam grupos marginalizados e permitam uma maior compreensão de uma variedade de etnias, culturas, origens socioeconômicas e orientações sexuais.

Palavras-chave: Educação; Justiça social; Era pós-digital.

\section{Introduction}

One of the most prevalent issues in educational settings is the fact that over the years, teachers' attention has been restricted to the classroom and not expanded to the broader aspects of schooling (SCHEFFLER, 1968; FREEDMAN ET AL, 1983; ZEICHNER, 2009). Teachers' goals must be linked to the social context of students, and such a requirement involves the critical analysis of the structure of schools as institutions and educational systems, as well as the various oppressions and injustices that underlie the complex scenario of teaching, which encompasses concepts such as ethnicity, class, gender, sexuality, religion, among others (ZEICHNER, 2009). Careful attention needs to be paid not to reinforce those oppressions and injustices, historically rooted in our societies and educational systems. 
Among those larger settings of schooling are technological advances, especially considering that mobile devices have been incorporating new forms of communication since the last two decades of the Twentieth century. As stated previously (LEUNG \& CHAN, 2003; SANTAELLA, 2013; LANKSHEAR \& KNOBEL, 2015; ZACCHI, 2018; SCHLINDWEIN, BRAGA \& BOA SORTE, 2019), the new forms of interaction facilitated by technology make frontiers between the virtual and non-virtual increasingly imprecise. As we are led to different ways of relating to one another, ubiquitous communication has impacted teaching and learning in the diverse contexts and knowledge areas. Those practices are not restricted to distance education per se. In a similar way in which language classrooms hybridized oral and written practices in the past, digital technologies have been incorporated over the years, allowing the expansion of teachers' instructional resources.

Nevertheless, teachers ought to consider the use of millions of data produced on a daily basis, particularly since the post-digital era is metaphorically questioning both hardware and software technologies, whose effects have potentialized social inequities around the world. Across the globe, people do not have equal access to the Internet, and the fact that technologies make it possible to change social contexts leads us to thinking about the actions that have to be at stake (JANKS, 2014). Access to technologies come with power relations, which can provoke irreversible damage to our students' development, particularly ones who are vulnerable. As Zeichner (2009) puts it, educational actions within schools - in non-neutral perspectives of teaching and teacher development - may contribute to the construction of more decent and just societies, making sure that the political elements of teaching do not get lost.

Historically marginalized groups, such as LGBTQI+, lower-class, women, and Black people have always been subject to hegemonic and discriminatory practices both in society and in schools. Neoliberal and conservative trends have threatened democracies around the world - consider Cambridge Analytica's interference on Brexit's and the USA's 2016 elections. Faced with phenomena such as those, teachers need to be prepared lest they do not reinforce injustices, which are already potentialized by digital technologies. Education for social justice taken as serious topic may help teachers rethink the way identities, sexuality, democracy, activism and geopolitics may be addressed in the classrooms, since reflecting on those issues is key to understanding in the post-digital era (SANTAELLA, 2016).

In this article, our argument to devoting increased attention towards education for social justice in a post-digital era is twofold. First, we will define education for social justice, given the significant and substantial studies in the field. Second, we will deepen conceptions that we 
consider to be essential for confronting problems of the post-digital era: (i) attention to neoliberalism and its impacts on education for social justice; (ii) attention to race, racism, and a claim for anti-oppressive education. We take into consideration that educating for social justice should not be about methods (COCHRAN-SMITH, 2010) but instead, encompass families and other essential elements underlying educational practices in contemporary times.

\section{Education for social justice: definitions}

In order to cover essential definitions of such a broad term as education for social justice, we depart from two pivotal arguments that will position the reader into what has been argued in the literature over the last two decades:

1. Cochran-Smith (2010, p. 450, our highlights), by dichotomizing justice / injustice makes a point on the striking changes in education policies and practices in economic and political contexts around the world (not only in the United States where her research takes place):

the distributive paradigm of justice, which grows out of liberal democratic theory, focuses on equality of individuals, civic engagement, and a common political commitment to all citizens' autonomy to pursue their own ideas of the good life (Rawls, 1971). Here injustice is defined as inequalities rooted in the socioeconomic structure of society, including exploitation, economic marginalization or deprivation of classes or class-like groups (Fraser, 2003). From this perspective, the remedy for injustice is redistribution of material and other goods, including opportunity, power, and access with the goal of establishing a society based on fairness and equality.

2. Leonard et al. (2010, p. 262) explain that strong theoretical roots of education for social justice are firmly entrenched into Paulo Freire's well-known assertion of the necessity to view the world through the eyes of the oppressed:

His conception of conscientização theorizes a critical reading of the worlds to rewrite the world. This reading provides the foundation for critical pedagogy, which supports views of practice that encourage both teachers and students to develop and understanding of the interconnecting relationship among ideology, power, and culture. An important aspect of Freire's concept of conscientização is a person's participation in his or her liberation. [...] In this way, greater outcomes can be expected because learners develop authority through full engagement in the learning process: a critical approach to teaching and learning. [...] It deals with addressing some form of hegemonic practice that results in marginalization or disenfranchisement of a specific group of people. 
The focal point that we settle while envisioning the previous concepts is the idea of social inequities (which goes much beyond social inequalities) as the front line of the fight against social injustices in education. The essence of conceptualizing education for social justice is striking in Freirian's explanation of conscientização because it is at the core of understanding cultures, ideologies and power relations that underlie hegemonic organizations and practices, whether they have educational purposes or not. Exploitation, marginalization, poverty, and the perpetuation of inequities around the world are disclosed when education for social justice is prioritized in schools alongside teacher education. This means that the comprehension of how power relations are constructed and maintained in our societies and institutions can help us engage in restructuring curricula, rethinking our approaches to teaching, and deepening our personal and professional relations towards promoting social justice.

Social change and activism are central to the vision of teaching and learning in educating for social justice, since both individual and collective actions are encouraged toward attenuating oppression (MCDONALD \& ZEICHNER, 2009). The question that most teachers engaged in pre-service and continuous formation would ask is, "how should it be done?" The case in point is providing opportunities to develop respect for individuals' differences and recognizing how these differences might be informed "by individuals' affiliations with particular social groups, such as those based on race, ethnicity, or class". (MCDONALD, 2005, p. 422).

First and foremost, we need to be cautious in regard to approaches and methods to teaching, especially because we are based on a Freirian perspective, which connects us to the critical analysis of our own context before taking broader looks. Agarwal et al. (2010) warn us that educating for social justice can be seen as an unattainable idea, not linked to particular classroom-based practices. In order to clarify this statement, they claim that educators who teach for social justice:

a) enact curricula that integrate multiple perspectives, question dominant Western narratives, and are inclusive of the racial, ethnic, and linguistic diversity $[\ldots]$;

b) support students to develop a critical consciousness of the injustices that characterize our society; and

c) scaffold opportunities for students to be active participants in a democracy, skilled in forms of civic engagement and deliberative discussion (AGARWAL ET AL, 2010, p. 238).

Full participation in educational reforms that support the reduction of inequities may be a viable way to improve educational opportunities. Students and teachers should be major agents into collective actions such as the ones mentioned by Agarwal et al (2010), not only in 
developing countries (e.g., in Latin America) but also in developed countries such as the United States. According to McDonald (2007), in North America, achieving social justice requires understanding the social structures that impact the lives of more vulnerable students such as students of color, low-income students, and English language learners.

Over time, educating for social justice has become an umbrella term encompassing a large range of practices and perspectives. Great variation in the use of this term has been registered as follows (ADAMS, BELL \& GRIFFIN, 2006; COCHRAN-SMITH, 2010):

- A dynamic concept that has been associated with different beliefs, practices, and policies across time (STURMAN, 1997; NORTH, 2008).

- Access for all students to high-quality teaching; preparing teachers for democratic engagement and the systematic political analysis of social inequities (SLEETER, 2009).

- Teachers' preparation with foci on one's own beliefs and identities, democratic education, including critical multicultural issues, antibias curriculum, and diversification of the teaching force in terms of cultural, racial, and linguistic backgrounds (DERMAN-SPARKS \& RAMSEY, 2006; SCHNIEDEWIND \& DAVIDSON，2006; SLEETER，2009，COCHRAN-SMITH， 2010; de OLIVEIRA, 2013).

- Culturally relevant pedagogy, culturally responsive and competent teachers, antiracist teaching, equity pedagogy, anti-oppressive teacher education, building classroom communities of dialogue both across and with difference (LADSONBILLINGS \& TATE, 1995; BERLAK \& MOYENDA, 2001; BANKS \& BANKS, 1995; KUMASHIRO, 2000, 2001).

Given the wide scope of possibilities that education for social justice offers to teachers' practices, it is critical to question the role that digital technologies have in the changes occurring in contemporary societies, such as variations in behavior, habits, as well as social and professional relations in the post-digital era. Coined by Cascone (2000), the term post-digital is best explained by Cramer (2015, p. 13), who uses it to describe "a contemporary disenchantment with digital information systems and media gadgets, or a period in which our fascination with these systems and gadgets has become historical” (CRAMER, 2015, p. 13). Nowadays, common sentiments of disenchantment and skepticism with technology are expressed by teachers' choices of using or foregoing advanced technologies in their classrooms, either because they do not have access to them or because they are not properly taught (nor 
even trained) to use them. On the side of the students, post-truth, misinformation and disinformation have been blurring the way that contents and their relationship with the world should be considered.

All of these elements impact the way education is supposed to be delivered in our schools. Since access to technologies is not the same to everyone, we need to seriously consider paradigm shifts such as neoliberalism as a key factor impairing the promotion of social justice. The following session covers neoliberal impacts on education for social justice, which, driven by myths such as meritocracy, hinders the fair distribution of power, opportunities, and access to everyone.

\section{Neoliberalism and its impact on education for social justice}

Neoliberalism is essentially related to the liberalization of economy, i.e., free trade, privatization, and deregulation. Such a logic is rooted in decreasing the government's expenses in order to increase the role that the private sector plays not only in economy, but also in society. We do not need to look far to find the effect of neoliberal policies when it comes to the unequal access to digital technologies, previously discussed in this article. In a post-digital era, those who have access to advanced technologies and possess decision-making power commonly come to decisions for everyone, even those who do not benefit from them. Consequently, neoliberalism is responsible for slowing down advances in public policies that democratize access to technologies.

In the context of downsizing public services, Sleeter (2009, p. 611) explains that the entire education enterprise has become "much more firmly harnessed to serve corporate interests" and leads us to what is known as "corporatocracy, the institutionalization of neoliberalism." Three powerful institutions that compose neoliberal governments are formed by conservatives, who aim to restructure the global order and increase their power over it:

Corporatocracy is a linkage of three powerful institutions that are run by a small elite whose members move "easily and often" across them: major corporations, government, and major banks. By gradually becoming more directly connected, these linked institutions have facilitated an increasingly powerful elite in building a global empire and accelerating elite wealth accumulation (SLEETER, 2009, p. 612, our highlights).

As far as teacher education is concerned, neoliberalism pushes teacher preparation away from educating for social justice, since education is seen as market competition, choice and 
privatization. Thus, teacher preparation turns its focus to training technicians responsible for raising students' test scores (HURSH, 2005; SLEETER, 2009). A typical example is showcased by Brazilian President Jair Bolsonaro's neoliberal and conservative agenda, which is mirrored in legislators' propositions such as ones from Ana Campagnolo, who supports "School without Party," a movement which claims that Brazilian schools have been politicized by left-wing teachers whose sole purpose is to indoctrinate students instead of "teaching content". As a result of that belief, the 2019 budget freezes (up to 42\%) drastically limited science funding and reduced the country's investment in research, particularly in humanities.

Moreover, meritocracy is another foundational myth that sustains neoliberalism. Milner (2010) explains meritocracy as the belief that people's success, status and position in life depends on one's efforts, whereas failure emanates solely from the lack of choice, ability, and effort of individuals. In other words, if you develop special abilities and skills, work hard, follow the law, and make the right decisions, you will succeed. Besides, the author posits that the myth of meritocracy does not consider systemic barriers and institutional structures that can prevent success. Meritocracy "also rejects issues that permeate policies and practices, such as racism, sexism, classism, and discrimination both in classroom and in society" (MILNER, 2010, p. 124). Arguments such as those reinforce the conservative belief that affirmative actions such as racial quotas for entering universities are not necessary. This assumption, rooted on the myth of meritocracy (i.e. if you study hard, you will pass) ignores the deeply-rooted racial inequity problems in Brazil, a historical debt that must be paid off.

Educating for social justice, in this context, means exposing the links that neoliberalism has with dominant political and economic paradigms, incisively unpacking ideologies that are geared towards rising inequities within the country (COCHRAN-SMITH ET AL, 2009). With this in mind, educators can utilize social media and streaming platforms (i.e. YouTube) as instruments of Internet activism. As Boa Sorte (2018) posited, the semantic web has given us the possibilities of remixing and decentralizing hegemonic discourses. Our students now have the ability to rewrite texts (videos, songs, photographs, posts) and modify widespread ideas masked by the dominant class, especially those which are stigmatized because of issues related to class, gender, ethnicity, sexuality and/or age. In the following section, we share stories about race and racism, two crucial elements of inequity in countries like Brazil and the United States. Moreover, we cover critical elements of anti-oppressive education, one of the key elements in advocating for social justice. 


\section{Race, racism, and a claim for anti-oppressive education}

In order to get a better grasp on issues of race and racism, consider the following vignette describing one of the co-authors' experience. As a White middle-class tenured Professor at a prestigious Brazilian Federal University, it took a personal experience in order for him to be able to fully understand what Milner (2008, p. 338) meant by "they [White people] are not unconcerned people per se - a focus on race just seems irrelevant and inconsequential to them because they do not live a reality that makes race important or of interest to them". His leftwing stance and support of social equity as opposed to social hierarchy served as the basis for his care and concerns about race issues, even though he admits his advocacy could have been more ardent in his teaching. However, while working as a Visiting Scholar in the United States, he had the opportunity to experience a reality that kept race in the forefront, especially because he was living in Miami, where more than $70 \%$ of the population consists of Latinos. He learned that he was not White in the United States and remained completely open to adding another identity to the construction of himself: he was now seen as a Latino or a person of color ${ }^{1}$. But that was not everything. Even when trying to be receptive to the new (at least to him) identity, as a Portuguese-speaking Brazilian, he had difficulty identifying himself as Latino when language is concerned, since the linguistic identity of Latinos in the US is stereotypically directed towards Spanish - a language Brazilians are usually not fluent in. When it comes to translanguaging, Brazilians try to speak Portuguese (or Portuñol) and negotiate meaning while carrying on daily tasks such as grocery shopping and sightseeing around the U.S. When language barrier is an issue, Brazilians usually revert to English to facilitate overall communication.

While living in Miami, whenever cashiers would call our Visiting Scholar to the checkout counters at stores, they would automatically identify him as Latino and assume he spoke Spanish, asking him “ ¿Todo estuvo bien?” instead of “Did you find everything OK?”. He was aware that it was his looks that drove the use of Spanish and understood why they became really confused when he did not understand their questions and attempted to repeat what they had said to them in English to try to establish some communication.

\footnotetext{
${ }^{1}$ In the U.S., according to the One Drop Rule, which emerged in the South as a means of racial segregation, a single drop of Black blood would make a person Black. Anthropologists call it the hypodescent rule, which states that people with mixed races get classified with the status of the subordinate race group (DAVIS, 1991).
} 
As demonstrated by the previous vignette, race plays an important role in how one is seen by others. This issue also takes us to a place where race matters in educational settings, even in cases when teachers and students do not face a reality which makes race a subject of interest to them. In other words, what happened to the co-author was something that is substantially stated in literature (LAWRENCE, 1997; BANKS, 2001; RICHERT ET AL, 2009), i.e., White teachers can only successfully take on the task of teaching about race and racism when they first understand their own racial identity.

In the early 1990's, Ladson-Billings \& Tate (1995) stated that race remained untheorized and it was a statistical and demographic documented factor of inequity. They highlighted that even when the concept of race fails to "make sense", we continue to employ it:

According to Nobel Laureate Toni Morrison: race has become metaphorical a way of referring to and disguising forces, events, classes, and expressions of social decay and economic division far more threatening to the body politic than biological "race" ever was. Expensively kept, economically unsound, a spurious and useless political asset in election campaigns, racism is as healthy today as it was during the Enlightenment. It seems that it has a utility far beyond economy, beyond the sequestering of classes from one another, and has assumed a metaphorical life so completely embedded in daily discourse that it is perhaps more necessary and more on display than ever before (LADSON-BILLINGS; TATE, 1995, p. 49).

More than 20 years later, what they had told us is still true, although, fortunately, race has been thoroughly theorized all over the world. Research theories such as Critical Race Theory (CRT) delve into how race and racism have been institutionalized and are maintained (SLEETER, 2017). As a core premise, CRT positions racism as endemic, institutional, and systematic - a fundamental way of organizing society rather than an aberration. Within education, CRT analyzes the Whiteness of teacher preparation and conceptualizes how it might be addressed, since the continued formation of teachers whom are not well equipped to teach racially, ethnically and linguistically diverse students is a product of racist systems designed to meet White needs (BELL, 1987; SOLÓRZANO \& BERNAL, 2001; MCGEE, 2016; SLEETER, 2017). This process is explained by Milner (2008) and Sleeter (2017) through the three tenets of CRT: interest convergence; claims of neutrality and color blindness; and experiential knowledge.

The first tenet, interest convergence, refers to the fact that people in power are, in theory, supportive of policies and practices that do not oppress and discriminate against others. Milner (2008) explains that Whites are willing to support those policies as long as they do not alter their own ways and systems, statuses, and privileges of experiencing life. This means that - 
Sleeter (2017) adds - Whites move forward interests of people of color only when they converge and advance White interests. Thus, we believe that the reason why affirmative actions (e.g. racial quotas) are not fully supported by a considerate number of White people is due to their fear that systemic changes will threaten them in personal ways such as losing status or control, i.e., gains for people of color mean losses for Whites.

The second tenet, claims of neutrality and color blindness, is geared towards dominant ideologies in policies and practices. As an example, Sleeter (2017) explains that neutrality and color blindness are visible when we do not look at racial disparities and historical racism while attributing people's widely different levels of success to talent and effort within a system of competitive individualism. This CRT tenet holds that claims of neutrality and color blindness clearly mask White privilege and power. According to Milner (2010, p. 12), stating that you see no color actually reveals "a privileged position that refuses to legitimize racial identifications that are very important to people of color and that are often used to justify inaction and perpetuation of the status quo."

The third tenet, experiential knowledge, assumes that the people who understand racism best are the ones who are routinely victimized by it rather than their perpetrators. Therefore, CRT values counterstories by people of color that call into question majoritarian stories, since dominant ideologies and knowledge systems based on White worldviews deny or mask racism (SOLÓRZANO \& YOSSO, 2002; SLEETER, 2017).

When it comes to educating for social justice, race and racism are strong factors that have to be taken into account when making decisions across varied curricula. Richert et al (2009) explain that White teachers must be prepared to incorporate students' racial identity development while selecting materials, planning curriculum, and implementing lessons about race and racism, no matter the field of expertise they are being prepared to teach. Forming teachers for social justice in the contemporary society means enabling them to be ready for challenges and management of their own and others' identities (TATUM, 1992; GAY, 2002; RICHERT ET AL, 2009).

This takes us to what is known as anti-oppressive education. In the United States, for example, claims for deconstructing stereotypes and myths disseminated by the media started to be strongly advocated in the late 1990's and early 2000's (KENWAY \& WILLIS, 1998; KUMASHIRO, 2000, 2001; WRIGHT, 2000), based on Paulo Freire's solid roots of critical pedagogy - which is in line with the perspective of education for social justice. Researchers have recognized and documented oppression as consisting of the harmful ways in which only 
certain students are treated in and by schools in regard to discrimination, harassment, physical and verbal abuse, as well as the exclusion and isolation of groups that are traditionally marginalized in societies such as people of color, unemployed/ underemployed families, students with disabilities, students from non-Christian religious backgrounds, and students who are male (or female) but do not exhibit hegemonic masculinity (femininity) (KENWAY \& WILLIS, 1998; KUMASHIRO, 2000).

Anti-oppressive education works towards changing this scenario, departing from reconceptualizing curricula and addressing different sorts of oppressions into all disciplines that are taught in schools. Unfortunately, teachers of "core disciplines" (such as mathematics and science) have been resistant to change. Their complaints rely on an alleged distance from the content they are supposed to teach to the subjects covered by anti-oppressive education - which, they argue, would be better covered by social studies. Nevertheless, not only is incorporating anti-oppressive discussions into each discipline possible, but it is also a question of rethinking the role of schools in diverse societies. Young (2010) explains one of the ways to approach antioppressive education in mathematics:

I suggested to the teachers that perhaps a discussion on U.S. resistance on the use of Fahrenheit as a system of measurement when no other country uses it might be fruitful. In other words, I raised the question of whether it was appropriate for the United States to compel the rest of the world to continue the use of the English system for the sole purpose of maintaining economic relations with the United States (YOUNG, 2010, p. 254).

Scholars have argued that mathematics has been a tool of colonialism and imperialism (BISHOP, 1990; KUMASHIRO, 2001), given that it has an underlying logic of control: "mathematizing and quantifying nature and time and space are ways for humans to control not only nature, but also society" (KUMASHIRO, 2001, p. 4). Teacher education that focuses on anti-oppressive topics is a possible way to understand the reasons why educating for social justice is so urgent nowadays. As far as mathematics and science are concerned, we need to learn that they have historically addressed certain problems rather than others, because different groups have not yet occupied prominent positions in those areas (HARDING, 1993; KUMASHIRO, 2001). Just as it happens with social studies, science and mathematics need to look beyond what is being represented and what is not.

In addition to making a strong investment in teacher education, Murray (2010) suggests the establishment of equity teams in schools in order to enable educators to communicate meaning across marginalized lines and address issues of social justice. Such goals can be 
achieved by analyzing academic achievement in schools, as well as dropout rates and the way disciplinary referrals are disproportionately represented by certain demographic groups. Moreover, the team should also analyze "perceptions, student learning, and school processes to eliminate the persistent patterns of differences in student achievement and experience by race, ethnicity, language, economics, ability, sexual orientation, and gender" (MURRAY, 2010, p. 49). The maintenance of these social justice values can be ensured by the constant analysis of educational data under critical lenses, which in turn will help educators to maintain their selfawareness and to prepare students to be critical thinkers.

\section{Final remarks}

This article discussed the importance of social change and activism as pivotal elements in education for social justice. Particularly in the post-digital era, when access to data and the latest technology remains limited to those in positions of power, teacher and teacher educators should strive to create environments which encourage exposure to perspectives that are inclusive of marginalized groups and allow for further understanding of a variety of ethnicities, cultures, socioeconomical backgrounds, and sexual orientations. In order to attain such goals, teachers must encourage culturally relevant pedagogy practices, including equity pedagogy and anti-oppressive education so that through open communication among teachers, students, and the community, stronger relationships can be built, which will benefit everyone involved. In view of this, it is important to highlight that race is socially constructed and not strictly linked to one's appearance. That is, someone may be considered White in Brazil but viewed as a person of color in the United States, where notions from the centuries-old one-drop rule can distinguish between those who are White and those who are not based solely on a single drop of blood (DAVIS, 1991). Such racial stigmas imposed by the dominant cultures further the marginalization of minorities and defy social justice. Therefore, it is important for those in positions of power (e.g., White educators) to become self-aware of the environment they live and, through constant reflection, appreciate differences and encourage counternarratives, incorporating those to the curriculum they teach (DYCHES \& BOYD, 2017; NORTH, 2008).

Education for social justice involves creating environments where there is a sense of belonging, solidarity, legitimacy, and uniqueness (as opposed to 'sameness') of each learner. Educators should make use of liberating pedagogies, which encourage dialogue, broaden and transform points of view, and support understanding the past in order to build a better future. 
Such bi-directional form of instruction allows both teachers and students to learn from each other through a constant dialogue that liberates both parties (FREIRE, 1974).

In the post-digital era, educating for social justice requires the use of technology in ways that instill self-reflection, empathy, and deeper relationships among learners of different religions, races, sexual orientations, and socioeconomic backgrounds, no matter if the technology is analog or digital. While analog technologies play important roles in understanding the dynamics of society, it is also our desire for teachers and teacher educators to take advantage of new available forms of communication. Access to information facilitated by technology can widen learners' perspectives in a manner which allows both sides to reflect upon the many facets - as opposed to one-sided stereotypes - involved in issues related to one's identity, race, socioeconomic and linguistic backgrounds, and political stances.

\section{REFERENCES}

Adams, M., Bell, L. A., \& Griffin, P. (Eds.). (2007). Teaching for diversity and social justice $\left(2^{\text {nd }} E d.\right)$. Routledge/Taylor \& Francis Group.

Agarwal et al. (2010). From ideal to practice and back again: Beginning teachers teaching for social justice. Journal of Teacher Education, 61(3), 237-247.

Banks, J. A. (2001). Citizenship Education and Diversity: Implications for Teacher Education. Journal of Teacher Education, 52(1), 5-16.

Banks, C.A.; Banks, J. (1995). Equity pedagogy: an essential component of multicultural education. Culturally relevant teaching. Summer, (34), 3, 152-158.

Bell, D. (1987). And we are not saved: the elusive quest for racial justice. New York: Basic Books.

Berlak, A.; Moyenda S. (2001). Taking it personally: racism in classroom from kindergarten to college. Chicago: The University of Chicago Press.

Bishop, A. J. (1990). Western mathematics: the secret weapon of cultural imperialism. Race \& Class, 32(2), 51-65.

Boa Sorte, P. (2018). Remixes e expressão escrita em língua inglesa. In: Jordão, C. M.; Martinez, J.; Monte Mór, W. (Eds). Letramentos em prática na formação inicial de professores de inglês. Campinas: Pontes, 279-291.

Cascone, K. (2000). The aesthetics of failure: "post-digital" tendencies in contemporary computer music. Computer music journal, Winter, (24), 4, 12-18, Massachussets Institute of Technology. 
Cochran-Smith, M. (2010). Toward a theory of teacher education for social justice. In A. Hargreaves et al. (Eds.), Second International Handbook of Educational Change (pp. 445467). New York: Springer.

Cochran-Smith, M. et al. (2009). Teacher education for social justice: Critiquing the critiques. In W. Ayers, T. Quinn, \& D. Stovall (Eds), Handbook of social justice in education (pp. 625-639). New York: Routledge.

Cramer, F. (2015). What is “post-digital”? In: Berry, D.; Dieter, M. (Eds). Post-digital aesthetics: art, computation and design. Palgrave, Macmillan.

Davis, F.J. (1991). Who is Black? One Nation's Definition. University Park, PA: Pennsylvania State University Press.

de Oliveira, L. C. (2013). Teacher education for social justice: perspectives and lessons learned. Charlotte. NC: Information Age Publishing.

Derman-Sparks, L.; Ramsay, P. G. (2006). What If All the Kids Are White? Anti-Bias Multicultural Education With Young Children and Families. New York: Teachers College Press.

Dyches, J., \& Boyd, A. (2017). Foregrounding equity in teacher education: Toward a model of social justice pedagogical and content knowledge. Journal of Teacher Education, 68(5), 476-490.

Freedman, S et al. (1983). Teaching: An imperilled "profession". In Shulman, L. S., Hr Sykes, G. (Eds.) Handbook of teaching and policy (pp. 261-299). New York/London: Longman.

Freire P. (1974/2010). Pedagogia do oprimido. São Paulo: Paz e Terra.

Gay, G. (2002). Preparing for culturally responsive teaching. Journal of Teacher Education, 53(2), 106-116.

Harding, S. (1993). The "Racial" Economy of Science. Bloomington: Indiana University Press.

Hursh, D. (2005). Neo-liberalism, markets and accountability: transforming education and undermining democracy in the United States and England. Policy futures in Education. (3), n.1, 2-15.

Janks, H. (2014). Doing critical literacy: texts and activities for students and teachers. New York: Routledge.

Kenway, J.; Willis, S. (1998). Answering back: girls, boys and feminism in schools. London \& New York: Routledge.

Kumashiro, K. K. (2000). Towards a theory of anti-oppressive education. Review of Educational Research, 70(1), 25-53. 
Kumashiro, K. K. (2001). "Posts"” perspectives on anti-oppressive education in social studies, English, mathematics, and science classrooms. Educational Researcher, 30(3), 3-12.

Lankshear, C.; Knobel, M. (2015). Remix, literacy and creativity: an analytic review of the research literature. Literacy Research Association Conference Symposium (4), 1-18.

Ladson-Billings, G., \& Tate, W. F. (1995). Toward a critical race theory of education. Teachers College Record, 97, 47-68.

Lawrence, S. M. (1997) Beyond race awareness: White racial identity and multicultural teaching. Journal of Teacher Education, march-april, (48), 2, 1-8.

Leonard et al (2010). The nuances and complexities of teaching mathematics for cultural relevance and social justice. Journal of Teacher Education, 61(3), 261-270.

Leung, C.H.; Chang, Y.Y. (2003). Mobile learning: a new paradigm in electronic learning. Proceedings of the $3^{\text {rd }}$ IEEE International Conference on Advanced Learning Technologies, 76-80. Los Alamitos. USA: IEEE.

McDonald, M. (2005). The integration of social justice in teacher education: Dimensions of prospective teachers' opportunities to learn. Journal of Teacher Education, 56(5), 418-435.

McDonald, M. (2007). The joint enterprise of social justice teacher education. Teachers College Record, 109(8), 2047-2081.

McDonald, M. \& Zeichner, K. (2009). Social justice teacher education. In W. Ayers, T. Quinn, \& D. Stovall (Eds), Handbook of social justice in education (pp. 595-610). New York: Routledge.

McGee, E. O. (2016). Devalued Black and Latino Racial Identities: A By-Product of STEM College Culture? American Educational Research Journal, 53(6), 1626-1662.

Milner, H. R. (2010). What does teacher education have to do with teaching? Implications for diversity studies. Journal of Teacher Education, 61(1-2), 118-131.

Milner, H. R. (2008). Critical race theory and interest convergence as analytic tools in teacher education policies and practices. Journal of Teacher Education, 59(4), 332-346.

Murray, O. (2010). A mindfulness to transcend pre-service lip-service: A call for K-12 schools to invest in social justice education. Multicultural Education, 17(3), 48-50.

North, C. E. (2008). What is all this talk about "social justice"? Mapping the terrain of education's latest catchphrase. Teachers College Record, 110(6), 1182-1206.

Richert, A. E et al. (2009). Preparing White teachers to teach in a racist nation: What do they need to know and be able to do. In W. Ayers, T. Quinn, \& D. Stovall (Eds), Handbook of social justice in education (pp. 640-653). New York: Routledge.

Santaella, L. (2016). Temas e dilemas do pós-digital: a voz da política. São Paulo: Paulus. 
Santaella, L. (2013). Comunicação ubíqua: representações na cultura e na educação. São Paulo: Paulus.

Solórzano, D. G.; Bernal, D. D. (2001). Examining Transformational Resistance Through a Critical Race and Latcrit Theory Framework: Chicana and Chicano Students in an Urban Context. Urban Education, 36(3), 308-342.

Solórzano, D. G.; Yosso, T. J. (2002). Critical Race Methodology: Counter-Storytelling as an Analytical Framework for Education Research. Qualitative Inquiry, 8(1), 23-44.

Scheffler, I. (1968). Science and subjectivity. British Journal for the Philosophy of Science, 19 (2): 176-177.

Schlindwein, A.F; Braga, D. B.; Boa Sorte, P. (2019). Ensino-aprendizagem de inglês com tecnologias: o caso da formação continuada para professores de inglês em Sergipe. In: Nascimento, A. K. O.; Zacchi, V.J. Formação docente em língua inglesa: diferentes perspectivas. Campinas: Mercado de Letras, 157-174.

Schniedewind, N.; Davidson, E. (2006). Open minds to equality: a sourcebook of learning activities to promote race, sex, class and age equity. Milwaukee. Rethinking Schools.

Sleeter, C. (2009). Teacher education, neoliberalism, and social justice. In W. Ayers, T. Quinn, \& D. Stovall (Eds), Handbook of social justice in education (pp. 611-624). New York: Routledge.

Sleeter, C. (2017). Critical race theory and the Whiteness of teacher education. Urban Education, 52(2), 155-169.

Sturman, A. (1997). Case study methods. In: J. P. Keeves (Ed.). Educational research, methodology and measurement: an international handbook $\left(2^{\text {nd }} E d.\right)$.Oxford: Pergamon, $61-66$.

Tatum, B. D. (1992). Talking about race, learning about racism: the application of racial identity development theory in the classroom. Harvard Educational Review. (62), N. 1, Spring, 1-24.

Wright, H. K. (2000). Nailing Jell-O to the Wall: Pinpointing Aspects of State- of-the-Art Curriculum Theorizing. Educational Researcher, 29(5), 4-13.

Young, E. (2010). Challenges to conceptualizing and actualizing culturally relevant pedagogy: How viable is the theory in classroom practice? Journal of Teacher Education, 61(3), 248-260.

Zacchi, V. J. (2018). Literacies and digital gaming: negotiating meanings in English language teacher education. Revista Tempos e Espaços em Educação, (1), 11, 153-168.

Zeichner, Z. (2009). Teacher education and the struggle for social justice. New York: Routledge. 


\section{ABOUT THE AUTHORS:}

\section{Paulo Boa Sorte}

Ph.D. in Applied Linguistics and Language Studies from the Pontifical Catholic University of São Paulo, Brazil (PUC-SP). Tenured Professor at the Department of Foreign Languages and the Graduate School of Education of the Federal University of Sergipe, Brazil (UFS). Currently holds Post-doctoral studies at the University of Miami, Florida, USA. At UFS, he is the leader of the research group TECLA: Tecnologias, Educação e Linguística Aplicada [Technologies, Education and Applied Linguistics]. E-mail: pauloboasorte1@gmail.com

(iD http://orcid.org/0000-0002-0785-5998

\section{Cristiane Vicentini}

Graduate Research Assistant and Ph.D. Student in Language and Literacy Learning in Multilingual Settings at the University of Miami, United States of America. She earned an M.A. in TESOL from Hawaii Pacific University, and an M.S. in Instructional Design and Technology from the University of Tampa. E-mail: cxr809@ miami.edu

iD http://orcid.org/0000-0002-2501-0315

Recebido em: 02 de novembro de 2019 Aprovado em: 29 de novembro de 2019

Publicado em: 01 de abril de 2020 